\title{
Assessment of Radionuclide Concentration in Surface Soil and Human Health Risk Associated with Exposure in Two Higher Institutions of Esan land, Edo State, Nigeria
}

\author{
1*POPOOLA, FA; ${ }^{2}$ FAKEYE, OD; ${ }^{3}$ BASIRU, QB; ${ }^{3}$ ADESINA, DA; ${ }^{4}$ SULOLA, \\ MA
}

${ }^{I}$ Department of Mathematical \& Physical Sciences, ${ }^{2}$ Department of Biological Sciences, College of Basic \& Applied Sciences, Samuel Adegboyega University, Ogwa, Edo State, Nigeria

${ }^{3}$ Department of Science Laboratory Technology, School of Science, ${ }^{4}$ Department of Mechanical Engineering, The Oke-Ogun Polytechnic Saki, Oyo State, Nigeria

*Corresponding Author Email: felixgoke@gmail.com

\begin{abstract}
The aim of this study is to assess the activity concentration of radionuclides and the possible health risk associated with exposure to radiation from the soil samples collected from two higher institutions in Esan land of Edo State, Nigeria. The gamma spectrometry system was used to determine the activity concentrations of radionuclides ${ }^{238} \mathrm{U}$, ${ }^{232} \mathrm{Th}$ and ${ }^{40} \mathrm{~K}$ in the surface soil samples. The activity concentration of radionuclides ranged from $7.16 \pm 0.63$ to $102.37 \pm 2.37 \mathrm{BqKg}^{-1}$ for ${ }^{40} \mathrm{~K}$, from $0.75 \pm 0.05$ to $3.13 \pm 0.11 \mathrm{BqKg}^{-1}$ for ${ }^{238} \mathrm{U}$ and from $2.25 \pm 0.20$ to $9.02 \pm$ $0.40 \mathrm{BqKg}{ }^{-1}$ for ${ }^{232} \mathrm{Th}$. The measured mean activity concentration of radionuclides for ${ }^{40} \mathrm{~K},{ }^{238} \mathrm{U}$ and ${ }^{232} \mathrm{Th}$ from the examined topsoil of Samuel Adegboyega University were $57.80 \pm 1.7 \mathrm{BqKg}^{-1} ; 2.07 \pm 0.09 \mathrm{BqKg}^{-1}$ and $6.89 \pm 0.34$ $\mathrm{BqKg}^{-1}$ respectively. At the neighbouring higher institution; College of Education, Igueben, the mean activity concentration of ${ }^{40} \mathrm{~K},{ }^{238} \mathrm{U}$ and ${ }^{232} \mathrm{Th}$ in its surface soil were $30.19 \pm 1.22 \mathrm{~Bq} \mathrm{Kg}^{-1}, 1.41 \pm 0.07 \mathrm{BqKg}^{-1}$ and $4.85 \pm 0.28$ $\mathrm{Bq} \mathrm{Kg}^{-1}$ respectively. The total mean values for radiation dose estimation for Radium Equivalent Activity, Absorbed Dose, Excess Lifetime Cancer Risk, Outdoor and Indoor Annual Effective Dose Equivalent are $13.20 \mathrm{BqKg}^{-1}, 6.03 \mathrm{nGy} / \mathrm{h}$, $0.026,7.40 \mu S v / y$, and $29.60 \mu S v / y$ respectively. These values were found to be lower than the global average values. Hence, there is no radiation induced health threat to the students and members of staff in the study area.
\end{abstract}

DOI: https://dx.doi.org/10.4314/jasem.v23i12.29

Copyright: Copyright $(C 2019$ Popoola et al. This is an open access article distributed under the Creative Commons Attribution License (CCL), which permits unrestricted use, distribution, and reproduction in any medium, provided the original work is properly cited.

Dates: Received: 30 November 2019; Revised: 20 December 2019; Accepted: 23 December 2019

Keywords: Soil, exposure, health risk, activity concentrations

Soils are complex combinations of minerals, organic compounds and living organisms that often interact in order to respond to natural forces and those exerted by biological, chemical and physical forces. The essential functions of soil in ecosystems comprise: sustainability of biological activity, diversity, and productivity; water and solute flow control and partitioning; filtration, buffering, degradation, immobilization, and detoxification of organic and inorganic materials, such as by-products from municipal and industrial activities, and atmospheric deposition; storage and cycling of nutrients and other earth-biosphere elements; and provision of support for socio-economic support of structures. (IAEA, 2004). The aforementioned factors can affect the soil quality and the role the soil plays in the ecosystem when the contaminants are present in high concentrations. External pollutants reaching the soil through wet or dry precipitation, such as radionuclides, trace elements or organic compounds, behave differently depending on the absorption properties, texture, density, humidity and other variables of each soil type. (IAEA, 2004). Soil is an essential environmental constituent for making bricks and houses. Radiation and radioactivity sources in the environment are numerous. The primary potential irradiation source of the human body is gamma radiation released by naturally occurring radionuclides (UNSCEAR, 1993). Naturally occurring radionuclides of terrestrial origin occur in all media, including human bodies, in various amounts. Such materials contain only those radionuclides of halflived close to the age of the Earth and their decay product (Ridha et al., 2015). External outdoor exposure is caused by terrestrial radionuclides that are available at trace levels in all soils depending on the rock formations from which the soils are derived (UNSCEAR, 2000). Internal exposure to naturally occurring radionuclides may be a significant risk factor, in particular in areas where natural radioactivity raises the pollution (Toader, 1997). Human beings are exposed to radiation from sources like cosmic rays, natural radionuclides in water, air, soil and vegetation; and artificial radioactivity emanating from medical use and effect from nucleartest applications. The soil's radioactivity is important as it is distributed in water and air, as well as in plants 
and other living beings (Zaim et al., 2016). River sediments are widely used as major construction materials for the building of residential and office complexes across Nigeria. Studies have revealed that radiation from building materials causes internal radiation exposure (Ononugbo et al., 2016). Therefore, it is the objective of this study to assess the radionuclide concentration of ${ }^{238} \mathrm{U},{ }^{232} \mathrm{Th}$ and ${ }^{40} \mathrm{~K}$ in samples of soil collected at Samuel Adegboyega University, Ogwa and College of Education, Igueben both at Esan Land of Edo State, Nigeria and estimate the potential health hazard to students and staff of that environment from radiation exposure. Soil radioactivity levels in this area are not previously known in literature; therefore the results of this study may serve as baseline for future study in Esan land.

\section{MATERIALS AND METHOD}

Study Area: Ogwa is a town where Samuel Adegboyega University is situated in Edo State's Esan west local government area, Nigeria. It is located approximately on latitude $6^{\circ} 30^{\prime} 20.16^{\prime \prime} \mathrm{N}$ and longitude $6^{\circ} 12^{\prime} 30.24^{\prime \prime} \mathrm{E}$. Igueben is the headquarters of the Igueben Local Government Area. Its coordinates in degree minutes seconds (DMS) latitude and longitude are $6^{\circ} 31^{\prime} 7.56^{\prime \prime} \mathrm{N}$ and $6^{\circ} 12^{\prime} 58.896^{\prime \prime} \mathrm{E}$ respectively. The two towns are an integral part of the Esan Land. This study area falls within the tropical region. High temperatures, high humidity, and heavy rainfall dominate the climate of a tropical environment. The region is distinguished by two distinct seasons: the wet season from March to November and the dry season from November to February (Magnus, 2011). This area is situated on a relatively flat plateau called the Esan plateau and it is approximately $466 \mathrm{~m}$ above the sea level (Akinbode, 1983). The vegetation is the mixed type of forest and Savannah, popularly called derived vegetation (Magnus, 2011).

Sample Collection and Processing: A total of nine samples of soil were collected randomly from the study area using conventional methods. At each sampling site, three to five were marked and samples were obtained by digging a $50 \mathrm{~cm}$ by $50 \mathrm{~cm}$ area. The samples from each site were thoroughly mixed together to form a single sample. About $4 \mathrm{~kg}$ of surface soil samples were collected and placed in black polythene bags. The bags were properly labeled at the point of collection and taken to the laboratory. Each sample was taken from a depth of $0 \sim 5 \mathrm{~cm}$ at the selected point. In the soil samples, plant roots, stones, gravel nails, and other extraneous objects were removed. After mixing thoroughly, the samples of soil were left to dry for five days under laboratory conditions to remove some of the humidity. The samples were weighed and then dried in an oven at $110^{\circ} \mathrm{C}$ for the purpose of drying the samples (Thabayneh et al., 2012, Usikalu et al., 2019). After crushing and thorough mixing, the samples were sieved with a $2 \mathrm{~mm}$ mesh screen, sieved, and packed in $250 \mathrm{~g}$ of each sample were placed in plastic containers, $8.5 \mathrm{~cm}$ in diameter and $5.6 \mathrm{~cm}$ high. After the containers have been weighed, they are sealed for 30 days to ensure secular equilibrium in the ${ }^{238} \mathrm{U}$ and ${ }^{232} \mathrm{Th}$ with their respective progeny (Usikalu et al., 2019, Ononugbo, et al., 2016). This means in order to allow for radon and its short-lived progenies to reach secular radioactive equilibrium prior to gamma spectroscopy (Thabayneh et al., 2012). The samples were then transported to the Radiation and Health Physics Laboratory of Ladoke Akintola University of Technology, Ogbomoso, Nigeria for gamma spectrometric measurement.

Gamma Spectroscopy Counting Procedure: The gamma spectrometry system employed in determining the activity concentrations of radionuclides ${ }^{238} \mathrm{U},{ }^{232} \mathrm{Th}$ and ${ }^{40} \mathrm{~K}$ for surface soil samples consists of a $3 \times 3$ inch $\mathrm{NaI}(\mathrm{Tl})$ detector a product of Princeton Gamma Tech., USA. The detector is housed in a cylindrical lead shield to reduce the effect of background radiation. The detector was coupled to Gamma Spectacular (model GS-2000 Pro) multichannel analyzer and further linked to a computer for display. Data acquisition and analysis of gamma-ray spectra were achieved using the Theremino software. Energy calibration of the detector was carried out using the RSS8 gamma source set traceable to Spectrum Techniques LLC, USA. It was accomplished by measuring the spectra of point sources emitting gamma-rays of precisely known energies and obtaining the measured peak positions of particular energies for $18000 \mathrm{~s}$. The efficiency calibration of the detector was also carried out using a reference standard source consisting of known radionuclide activities: ${ }^{40} \mathrm{~K}(578.4 \mathrm{keV}),{ }^{238} \mathrm{U}(20.9 \mathrm{keV})$ and ${ }^{232} \mathrm{Th}$ (10.47 keV).

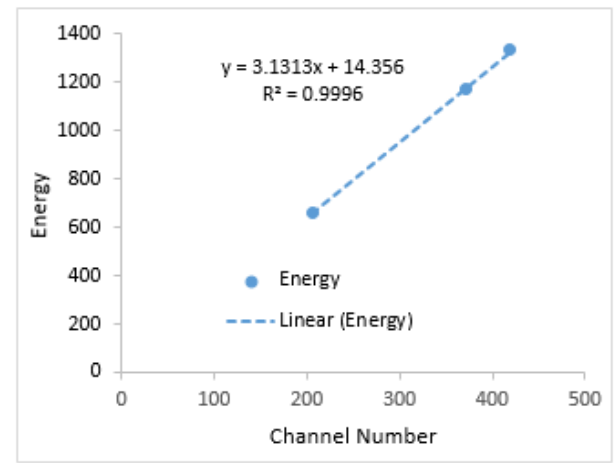

Fig 1a: Calibration Graph for energy against channel number 


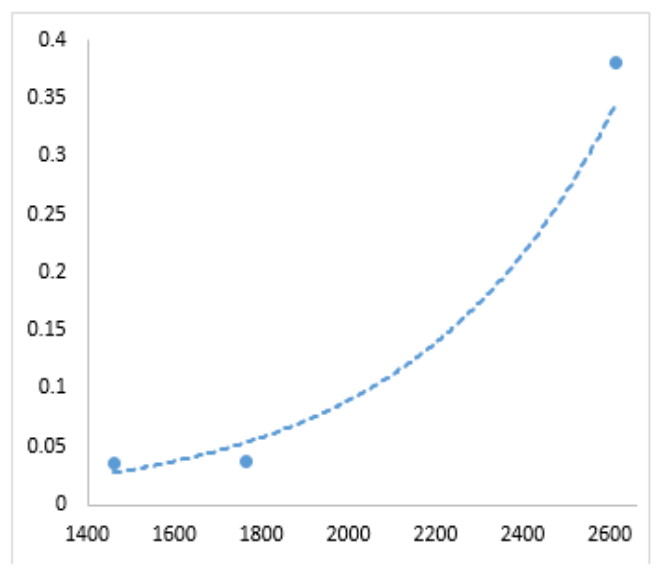

Fig 1b: Efficiency Calibration Curve

Prior to the sample measurement, an empty container was counted for $18000 \mathrm{~s}$ so as to determine the background gamma-ray, distribution count. The sealed samples after attaining a state of secular equilibrium were each placed on the detector for analysis one after the other. Each sample was then counted for the same period of time as that of the empty container. The characteristics of the radionuclides used to measure the activity concentrations of the sample are 1460.0 $\mathrm{keV}\left({ }^{40} \mathrm{~K}\right), 1764.5 \mathrm{keV}$ of ${ }^{214} \mathrm{Bi}\left({ }^{238} \mathrm{U}\right)$, and $2614.7 \mathrm{keV}$ of ${ }^{208} \mathrm{Tl}\left({ }^{232} \mathrm{Th}\right)$.
The activity concentration $\left(C_{S}\right)$ of the radionuclide was calculated using the following expression (Ilori et al., 2017; Orosun et al., 2016):

$$
C_{S}=\frac{C_{\alpha}}{P_{\gamma}\left(\frac{M_{S}}{V_{S}}\right) \varepsilon_{\gamma} t_{c}}\left(\mathrm{BqKg}^{-1}\right)
$$

Where $C s$ is the sample concentration, $C_{\alpha}$ is the net peak energy, $\varepsilon_{\gamma}$ is the efficiency of the detector for a $\gamma$ - energy of interest, $\frac{M_{S}}{V_{S}}$ is the sample mass per volume of soil, $t_{c}$ is the total counting time and $P_{\gamma}$ is abundance of the $\gamma$ - line in a radionuclide.

\section{RESULT AND DISCUSSION}

Activity Concentration: The concentration of the activities of ${ }^{238} \mathrm{U},{ }^{232} \mathrm{Th}$ and ${ }^{40} \mathrm{~K}$ in each of the nine (9) topsoil samples that were analyzed are presented in Table 1 . The activity concentration of radionuclides ranges from $7.16 \pm 0.63$ to $102.37 \pm 2.37 \mathrm{BqKg}^{-1}$ for ${ }^{40} \mathrm{~K}$, from $0.75 \pm 0.05$ to $3.13 \pm 0.11 \mathrm{BqKg}^{-1}$ for ${ }^{238} \mathrm{U}$ and from $2.25 \pm 0.20$ to $9.02 \pm$ $0.40 \mathrm{BqKg}^{-1}$ for ${ }^{232} \mathrm{Th}$. Sample SAU1 in Samuel Adegboyega University records the highest activity concentration for all radionuclides while $\mathrm{CoE} 5$ has the minimum record value for the radionuclides' activity concentration.

Table 1. Activity concentrations of radioactivity in topsoil samples collected at the study sites

\begin{tabular}{llllll}
\hline S/n & Sample ID & Location & $\left.{ }^{40} \mathrm{~K}_{(\mathrm{BqKg}}^{-1}\right)$ & ${ }^{238} \mathrm{U}\left(\mathrm{Bq} \mathrm{Kg}^{-1}\right)$ & ${ }^{232} \mathrm{Th}^{\left(\mathrm{BqKg}^{-1}\right)}$ \\
\hline $\mathbf{1}$ & SAU1 & Male hostel & $102.37 \pm 2.37$ & $3.13 \pm 0.11$ & $9.02 \pm 0.40$ \\
$\mathbf{2}$ & SAU2 & Main Auditorium & $28.15 \pm 1.24$ & $1.14 \pm 0.07$ & $5.69 \pm 0.31$ \\
$\mathbf{3}$ & SAU3 & COLBAS & $77.44 \pm 2.06$ & $2.68 \pm 0.10$ & $8.27 \pm 0.38$ \\
$\mathbf{4}$ & SAU4 & Esan House & $23.23 \pm 1.13$ & $1.32 \pm 0.07$ & $4.58 \pm 0.28$ \\
& Mean Activity Concentration & $\mathbf{5 7 . 8 0} \pm \mathbf{1 . 7}$ & $\mathbf{2 . 0 7} \pm \mathbf{0 . 0 9}$ & $\mathbf{6 . 8 9} \pm \mathbf{0 . 3 4}$ \\
$\mathbf{5}$ & CoE1 & School of Science & $37.22 \pm 1.43$ & $1.88 \pm 0.08$ & $6.03 \pm 0.32$ \\
$\mathbf{6}$ & CoE2 & Lecturers Block & $24.27 \pm 1.15$ & $0.89 \pm 0.06$ & $3.24 \pm 0.24$ \\
$\mathbf{7}$ & CoE3 & School of Education & $63.40 \pm 1.86$ & $2.46 \pm 0.10$ & $8.44 \pm 0.38$ \\
$\mathbf{8}$ & CoE4 & Main Auditorium & $18.91 \pm 1.02$ & $1.06 \pm 0.06$ & $4.30 \pm 0.27$ \\
$\mathbf{9}$ & CoE5 & IJMB Lecture Hall & $7.16 \pm 0.63$ & $0.75 \pm 0.05$ & $2.25 \pm 0.20$ \\
& Mean Activity Concentration & $\mathbf{3 0 . 1 9} \pm \mathbf{1 . 2 2}$ & $\mathbf{1 . 4 1} \pm \mathbf{0 . 0 7}$ & $\mathbf{4 . 8 5} \pm \mathbf{0 . 2 8}$ \\
\hline
\end{tabular}

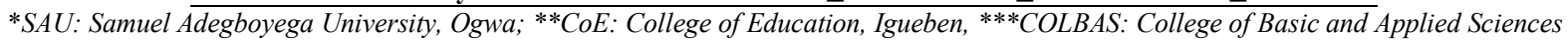

The measured mean activity concentration of radionuclides for ${ }^{40} \mathrm{~K},{ }^{238} \mathrm{U}$ and ${ }^{232} \mathrm{Th}$ from the examined topsoil of Samuel Adegboyega University is $57.80 \pm 1.7 \mathrm{BqKg}^{-1} ; 2.07 \pm 0.09 \mathrm{BqKg}^{-1}$ and $6.89 \pm$ $0.34 \mathrm{BqKg}^{-1}$ respectively. At the neighbouring higher institution; College of Education, Igueben, the mean activity concentration of radionuclides from the surface soil presented that the mean concentration of ${ }^{40} \mathrm{~K},{ }^{238} \mathrm{U}$ and ${ }^{232} \mathrm{Th}$ were $30.19 \pm 1.22 \mathrm{BqKg}^{-1}, 1.41 \pm$ $0.07 \mathrm{BqKg}^{-1}$ and $4.85 \pm 0.28 \mathrm{BqKg}^{-1}$ respectively. The results indicate that the soils in Samuel Adegboyega University are enriched with ${ }^{40} \mathrm{~K}$ than the surface soil in the College of Education, Igueben. Comparing these values with the worldwide average of 400,35 , and $30 \mathrm{BqKg}^{-1}$ set by UNSCEAR, (2000) for activity concentration of ${ }^{40} \mathrm{~K},{ }^{238} \mathrm{U}$ and ${ }^{232} \mathrm{Th}$ respectively, the values obtained in this study is minute and thus poise no significant health threat to the students and staffers in examined citadels of learning. A comparison of the radioactivity concentration of ${ }^{238} \mathrm{U},{ }^{232} \mathrm{Th}$ and ${ }^{40} \mathrm{~K}$ measured in surface soil in this study with other parts of Nigeria and other countries of the world are presented in Table 2 . 
Table 2: Comparison of radioactivity concentration of ${ }^{238} \mathrm{U},{ }^{232} \mathrm{Th}$ and ${ }^{40} \mathrm{~K}$ measured in surface soil in the present study with other parts of Nigeria and other countries of the world

\begin{tabular}{lllll}
\hline $\mathbf{U ~ B q k g}^{-1}$ & Th Bqkg $^{-1}$ & $\mathbf{K ~ B q k g}^{-1}$ & Country & Reference \\
\hline 2.07 & 6.89 & 57.80 & Nigeria (Ogwa, Edo) & This study \\
1.41 & 4.85 & 30.19 & Nigeria (Igueben, Edo) & This study \\
11.47 & 10.44 & 403.07 & Nigeria (Agege, Lagos) & Ilori et al., 2017 \\
19.72 & 220.50 & 920.16 & India (Hoshiarpur, Punjab) & Mehra et al., 2010 \\
128.05 & 24.8 & 455.05 & Nigeria (Ijero, Ekiti) & Usikalu et al., 2019 \\
39.0 & 7.73 & 278 & Saudi Arabia(Ras Tanura Refinery) & Alshahri and El-Taher, 2019 \\
71.6 & 83.9 & 451.1 & Turkey (Karadağ Mountain) & Korkmaz et al., 2017 \\
- & 54.07 & 580.6 & Bangladesh (Satkhira) & Hossen and Ferdous, 2015 \\
24.5 & 51.8 & 344.9 & Turkey (Rize Provine) & Durusoy and Yildirim, 2017 \\
12.14 & 23.23 & 270.14 & Nigeria (Fashina, Ile-Ife) & Oluyide et al., 2019 \\
26 & 29 & 923 & China (Bayanwula) & Bai, et al., 2017 \\
35 & 30 & 420 & World Average & UNSCEAR, 2000 \\
\hline
\end{tabular}

Estimation of Radiation Hazard Index: The radiation hazard indices are usually determined by the activity concentrations of ${ }^{238} \mathrm{U},{ }^{232} \mathrm{Th}$, and ${ }^{40} \mathrm{~K}$. The radiological parameters calculated to estimate the exposure risk in this study include indices of radium equivalent activity, absorbed gamma dose rate, annual effective dose equivalent, and excess lifetime cancer risk. These are presented in Table 3.

Radium Equivalent activity $\left(R a_{e q}\right)$ : The Radium Equivalent Activity $\left(R a_{e q}\right)$ index provides a guideline for regulating radiation protection safety standards for the general public residing on the area under investigation. The $R a_{e q}$ index represents a weighted sum of the activities of the aforementioned natural radionuclides (Hossen \& Ferdous, 2015). The index was calculated by the following relation (Orosun, et al., 2016; Bashiru et al., 2018; Ridha et al. 2015):

$$
R a_{e q}=C_{U}+1.43 C_{T h}+0.077 C_{K}
$$

Where $C_{U}, C_{T h}, C_{K}$ are the radioactivity concentration of ${ }^{238} \mathrm{U},{ }^{232} \mathrm{Th}$ and ${ }^{40} \mathrm{~K}$ respectively, measured in $\mathrm{BqKg}^{-1}$.

The calculated radium equivalent activities of soil samples are shown in Table (3). The minimum value is $4.52 \mathrm{~Bq} \mathrm{Kg}^{-1}$ noted in the sample (CoE5) while the maximum value of $23.91 \mathrm{BqKg}^{-1}$ is recorded in the sample (SAU1), with an average value of $13.20 \mathrm{BqKg}^{-1}$. The values of radium equivalent indices for all examined soil samples have a value lower than $370 \mathrm{~Bq} / \mathrm{kg}$ recommended by UNSCEAR (2000).

Absorbed Dose Rate $\left(D_{R}\right)$ : The absorbed dose is a measure of the energy deposited by ionizing radiation per unit mass in a medium. It can be expressed as joules per kilogram and represented by the equivalent S.I. unit, gray (Gy). The absorbed dose rate $D_{R}\left(n G y h^{-1}\right)$, due to activity concentration of ${ }^{238} \mathrm{U},{ }^{232} \mathrm{Th}$, and ${ }^{40} \mathrm{~K}$ was calculated using equation (3):

$$
\begin{gathered}
D_{R}\left(n G y h^{-1}\right)=R_{U} C_{U}+R_{T h} C_{T h}+ \\
R_{K} C_{K} \text { (3) }
\end{gathered}
$$

Where, $C_{U}, C_{T h}, C_{K}$ are the radioactivity concentration in $\mathrm{BqKg}^{-1}$ and $R_{U}, R_{T h}$, and $R_{K}$ are dose conversion factors which are $0.462,0.604$ and 0.0417 for ${ }^{238} \mathrm{U}$, ${ }^{232} \mathrm{Th}$, and ${ }^{40} \mathrm{~K}$ respectively (Oluyide et al., 2019; Orosun, et al., 2016; UNSCEAR, 2000; Ononugbo et al., 2016).

As presented in Table 3, the absorbed dose rate is found to vary from a minimum value of 2.00 (CoE5) to a maximum value of $11.16 n G y h^{-1}$ (SAU1). The mean absorbed dose rate estimated is $7.53 n G y h^{-1}$ and $4.84 n G y h^{-1}$ for the University and College respectively. The total mean and the mean absorbed dose rates obtained for all the locations are lower than the recommended average worldwide value of 55 $n G y h^{-1}$ (UNSCEAR, 2000).

Annual Effective Dose Equivalent (AEDE): The Effective Dose is a dose quantity defined by the International Commission on Radiation Protection to monitor and control human exposure to ionizing radiation.

It is the tissue-weighted sum of the equivalent doses in all specified tissues and organs of the body and represents the stochastic health risks to the whole body. It takes into account the type of radiation and the nature of each organ or tissue being irradiated, and enables summation of organ doses due to varying levels and types of radiation, both internal and external, to produce an overall calculated effective dose.

This combines both internal and external exposures (Orosun, et al., 2016). The indoor AEDE occurs within a house and accounts for the radiation risks resulting from the use of the soil as building material whereas the outdoor AEDE connote consideration of 
the absorbed dose emitted from radionuclide like ${ }^{238} \mathrm{U}$, ${ }^{232} \mathrm{Th}$, and ${ }^{40} \mathrm{~K}$ in the environment consider

The annual effective dose is given to express the irradiated dose of the human body from naturally existing radionuclides present in the earth's crust soil. The following relation expresses it.

$$
\begin{gathered}
A E D E=D_{R} \times 8760 h \times 0.2(\text { or } 0.8) \times 0.7 \times \\
10^{-3}(4)
\end{gathered}
$$

Where AEDE is annual effective dose $\left(\mu S v y^{-1}\right) ; D_{R}$ is dose rate $\left(n G y h^{-1}\right)$; the coefficient $0.7 S v G y^{-1}$ is for the conversion coefficient from the absorbed dose in the air to the effective dose received by adults; 0.2 for the outdoor occupancy factor; 8760 hours/year is equal to 365 days $\times 24$ h per year (Bai, et al., 2017).

The estimated annual outdoor effective doses ranged from 2.46 to $13.69 \mu S v y^{-1}$ with a mean value of $7.40 \mu S v y^{-1}$ while the annual indoor effective doses ranged from 9.83 to $54.76 \mu S v y^{-1}$ with an average value of $29.60 \mu S v y^{-1}$. Comparing the values obtained with $0.07 \mathrm{mSvy}^{-1}, 0.41 \mathrm{mSvy}^{-1}$ and 0.48 $m S v y^{-1}$ that UNSCEAR (2000) set as the standard for outdoor, indoor and worldwide average exposure respectively, the radiation levels in the study areas poise no significant health burden to human and the environment at large.

Excess Lifetime Cancer Risk (ELCR): The lifetime cancer risk interests with the possibility of growing cancer over a certain exposure grade. The Excess Lifetime cancer risk (ELCR) was computed using equation (7)

$$
E L C R=A E D E \times L S \times R F
$$

Where AEDE is the annual effective dose equivalent, LS is the mean life span $(\approx 70$ years $)$ and RF is the mortal cancer risk factor per Sievert (Cengiz and Çağlar, 2017). For stochastic impacts, ICRP exploits $\mathrm{RF}$ as 0.05 for the public (Orosun et al., 2016, Cengiz and Çağlar, 2017). For ELCR, the world's permissible standard value is given as $0.29 \times 10^{-3}$ (UNSCEAR 2000). The mean ELCR obtained for the study areas was $0.026 \times 10^{-3}$. This indicates that students and staffers in these areas are safe and not at risk of radiation hazards.

Table 3. Radium Equivalent Activity $\left(\mathrm{RA}_{\mathrm{eq}}\right)$, Absorbed Dose $\left(D_{R}\right)$, Annual Effective Dose Equivalent (AEDE) and Excess Lifetime Cancer Risk (ELCR) in topsoil samples collected at the study sites

\begin{tabular}{lllllll}
\hline $\begin{array}{l}\text { Sample } \\
\text { ID }\end{array}$ & Location & $\begin{array}{c}\mathbf{R A}_{v q} \\
\left(\mathrm{BqKg}^{-1}\right)\end{array}$ & $\begin{array}{c}\mathbf{D}_{g} \\
(n G y / h)\end{array}$ & $\begin{array}{l}\text { AEDE } \\
(\mu S v / y)\end{array}$ & \multicolumn{3}{c}{$\begin{array}{c}\text { ELCR } \\
\mathbf{1 0}\end{array}$} \\
\hline & & & & Outdoor & Indoor \\
\hline SAU1 & Male hostel & 23.91 & 11.16 & 13.69 & 54.76 & 0.048 \\
SAU2 & Main Auditorium & 11.44 & 5.14 & 6.30 & 25.20 & 0.022 \\
SAU3 & COLBAS & 20.47 & 9.46 & 11.60 & 46.42 & 0.041 \\
SAU4 & Egan House & 9.66 & 4.34 & 5.33 & 21.31 & 0.019 \\
Mean & & $\mathbf{1 6 . 3 7}$ & $\mathbf{7 . 5 3}$ & $\mathbf{9 . 2 3}$ & $\mathbf{3 6 . 9 2}$ & $\mathbf{0 . 0 3 2}$ \\
CoE1 & School of Science & 13.37 & 6.06 & 7.44 & 29.74 & 0.026 \\
CoE2 & Lecturers Block & 7.39 & 3.38 & 4.15 & 16.58 & 0.015 \\
CoE3 & School of Education & 19.41 & 8.88 & 10.89 & 43.55 & 0.038 \\
CoE4 & Main Auditorium & 8.67 & 3.88 & 4.75 & 19.01 & 0.017 \\
CoE5 & IMMB Lecture Hall & 4.52 & 2.00 & 2.46 & 9.83 & 0.009 \\
Mean & & $\mathbf{1 0 . 6 7}$ & $\mathbf{4 . 8 4}$ & $\mathbf{5 . 9 4}$ & $\mathbf{2 3 . 7 4}$ & $\mathbf{0 . 0 2 1}$ \\
Total Mean & & $\mathbf{1 3 . 2 0}$ & $\mathbf{6 . 0 3}$ & $\mathbf{7 . 4 0}$ & $\mathbf{2 9 . 6 0}$ & $\mathbf{0 . 0 2 6}$ \\
\hline
\end{tabular}

*SAU: Samuel Adegboyega University, Ogwa **CoE: College of Education, Igueben, ***COLBAS: College of Basic and Applied Sciences

Conclusion: The radioactivity concentration of ${ }^{238} \mathrm{U}$, ${ }^{232} \mathrm{Th}$ and ${ }^{40} \mathrm{~K}$ and the corresponding radiological hazard indices in the topsoil of two citadel of learning in Edo State, Nigeria has been evaluated using gamma spectrometry detector. Though the activity concentrations of the radionuclides and the mean radiological hazard indices obtained in Samuel Adegboyega University, Ogwa is higher than that of College of Education, Igueben but both are found to lie between the global safe limits. Consequently, the results of this study may serve as reference for future study in Esan land.

\section{REFERENCES}

Akinbode A (1983). The Geography of Ekpoma. Ekpoma: Bendel State University Press.

Alshahri1, F; El-Taher, A (2019). Investigation of natural radioactivity levels and evaluation of radiation hazards in residential-area soil near a Ras Tanura Refinery, Saudi Arabia. Pol. J. Environ. Stud. 28(1): 25 - 34

Bai, H; Hu, B; Wang, C; Bao, S; Sai, G; Xu, X; Zhang, $\mathrm{S}$; Li, Y (2017). Assessment of radioactive materials and heavy metals in the surface soil 
around the Bayanwula Prospective Uranium Mining Area in China. Int. J. of Environ. Res. \& Pub. Health. 14: 300

Bashiru, L; Sombo, T; Tyovenda, AA; Onukwube, SI; Nwankwo, MO (2018). Assessment of environmental radioactivity of surface soils in some selected Local Government Area in Benue State. IOSR J. of Appl. Phys. 10(3): 84 - 90

Cengiz, GB; Çağlar A (2017). Evaluation of natural radioactivity levels and radiological hazards in soil samples of Sarıkamış Province, Kars, Turkey. Radiat. Sci. and Technol. 3(6): 68 - 73. doi: 10.11648/j.rst.20170306.13

Durusoy, A; Yildirim M (2017). Determination of radioactivity concentrations in soil samples and dose assessment for Rize Province, Turkey. J. of Radiat. Res. and Appl. Sci. 10: 348 - 352

Hossen, MA; Ferdous, N (2015). Determination of radiological hazards and the transfer factors of radionuclides from soil to vegetables in the Southwestern District of Bangladesh. J. of Phys. Sci. 26(1): $83-98$

Ilori, AO; Alausa, SK; Ajanaku, O (2017). Activity concentrations, absorbed dose rate and annual effective dose of surface soils of Agege, Lagos State, Southwestern Nigeria. J. of the National Assoc. of Math. Phys. 42: 357 - 360

International Atomic Energy Agency (2004). Soil sampling for environmental contaminants. IAEATECDOC-1415, Vienna.

Korkmaz, ME; Agar, O; Uzun, E (2017). Assessment of natural radioactivity levels for Karadağ Mountain, Turkey. Int. J. of Radiat. Res. 15(4): 399 - 406

Magnus, OO (2011). Assessment of rain water harvesting facilities in Esan Land of Edo State, Nigeria. $J$. Hum. Ecol. 34(1): 7 - 16

Mehra, R; Badhan, K; Sonkawade, RG; Kansal, S; Singh $S$ (2010). Analysis of terrestrial natural radionuclides in soil samples and assessment of average effective dose. Indian J. of Pure \& Appl. Phys. 48: 805 - 808

Oluyide, SO; Tchokossa, P; Orosun, MM; Akinyose, FC; Louis, H; Ige, SO (2019). Natural radioactivity and radiological impact assessment of soil, food and water around iron and steel smelting area in Fashina Village, Ile-Ife, Osun State, Nigeria. $J$. Appl. Sci. Environ. Manage. 23(1): 135 - 143
Ononugbo, CP; Avwiri, GO; Ogan, CA (2016). Natural radioactivity measurement and evaluation of radiological hazards in sediment of Imo River, In Rivers State, Nigeria by Gamma Ray Spectrometry. IOSR J. of Appl. Phys. 8(3): 75 - 83 DOI: $10.9790 / 4861-0803017583$

Orosun. MM; Lawal, TO; Akinyose, FC (2016). Natural radionuclide concentrations and radiological impact assessment of soil and water in TankeIlorin, Nigeria. Zimbabwe J. of Sci. \& Technol. 11: $158-172$

Ridha, AA; Mutter, MM; Salim, MD (2015). Estimation of natural radioactivity in surface soil samples from Baghdad, Nahrain and Al-Mustansiriyah Universities Using Gamma-Ray Spectroscopy. J. of Coll. of Educat. 5: 61 - 74.

Thabayneh, KM; Jazzar, MM (2012). Natural radioactivity levels and estimation of radiation exposure in environmental soil samples from Tulkarem Province-Palestine. Open J. of Soil Sci. 2: 7 - 16

Toader, M; Vasilache, RA; Tomulescu, V (1997). ${ }^{226} \mathrm{Ra}$ intake in the population from Bucharest during the past ten years. IRPA Regional Symposium "Radiation Protection in Neighboring Countries of Central Europe" Prague, Czech Republic. September 8-12 1997

United Nations Scientific Committee on the Effect of Atomic Radiation (UNSCEAR) (2000). Report to the General Assembly. Annex B: Exposures from Natural Radiation Sources, United Nations, New York.

United Nations Scientific Committee on the Effects of Atomic Radiation, "Sources and Effects of Ionizing Radiation," UNSCEAR Report, New York, 1993.

Usikalu, MR; Maleka, PP; Ndlovu, NB; Zongo, S; Achuka, JA; Abodunrin, TJ (2019). Radiation dose assessment of soil from Ijero Ekiti, Nigeria. Cogent Engineer. $\quad 6$ : 1586271 https://doi.org/10.1080/23311916.2019.1586271

Zaim, N; Tugrul, AB; Atlas, H; Buyuk, B; Demir, E; Baydogan, N; Altınsoy, N (2016). Investigation of natural radioactivity of surface soil samples in the vicinity of Edirne-Turkey. Acta Physica Pol. A, 130(1): $64-67$ 